\title{
Sodium chloride as effective antifungal treatment for artificial egg incubation in Austropotamobius pallipes
}

\author{
T. Policar ${ }^{(1)}$, J. Smyth(2), M. Flanigan ${ }^{(3)}$, A. Kouba(1), P. Kozák(1)
}

Received January 2, 2011

Revised March 6, 2011

Accepted March 22, 2011

\section{ABSTRACT}

Key-words: formaldehyde, fungicide treatment, hatching, sodium chloride, white-clawed crayfish

\begin{abstract}
In this study, sodium chloride at three different concentrations, 30000 ppm (S30), 60000 ppm (S60) and 90000 ppm (S90), and formaldehyde at one concentration, $3000 \mathrm{ppm}(\mathrm{F})$, were tested as antifungal chemicals during artificial incubation (Al) of Austropotamobius pallipes eggs. Two treatments were tested without chemicals as control groups with $(R)$ and without $(C)$ the removal of dead eggs. After Al, formaldehyde treatment ensured high survival of stage $1(89.7 \pm 2.3 \%)$ and stage 2 $(85.5 \pm 2.4 \%)$ of juveniles. However, comparable survival rate to stage 1 and stage $2(85.5 \pm 5.5 \%$ and $80.6 \pm 3.2 \%)$ were also found in the treatment with the highest sodium chloride concentration (S90). Significantly lower survival rate of juveniles (stage 1: $60.6-70.3 \%$ and stage 2: 56.1-67.3\%) were evident in groups S60, S30 and R. However, group R demanded high labor and related costs. The lowest juvenile survival levels to stage $1(46.4 \pm 8.2 \%)$ and stage $2(45.2 \pm 6.8 \%)$ were observed in treatments without fungicide chemicals and removal of dead eggs $(C)$.
\end{abstract}

\section{RÉSUMÉ}

Le chlorure de sodium comme traitement antifongique efficace dans l'incubation artificielle des œufs d'Austropotamobius pallipes

Mots-clés : formaldéhyde, traitement antifongique, éclosion, chlorure de sodium, écrevisse à pieds blancs
Dans cette étude, le chlorure de sodium à trois différentes concentrations, 30000 ppm (S30), 60000 ppm (S60) et 90000 ppm (S90), et le formol à une concentration de 3000 ppm (F) ont été testés comme produits antifongiques pendant l'incubation artificielle (AI) d'œufs d'Austropotamobius pallipes. Deux traitements ont été testés sans produits antifongiques comme témoins avec (R) et sans $(\mathrm{C})$ retrait des œufs morts. Après incubation artificielle, le traitement au formol assure une survie élevée au stade $1(89,7 \pm 2,3 \%)$ et au stade $2(85,5 \pm 2,4 \%)$ des juvéniles. Toutefois, un taux de survie comparable au stade 1 et $2(85,5 \pm 5,5 \%$ et $80,6 \pm 3,2 \%)$ a été trouvé avec le traitement à la plus forte concentration en chlorure de sodium (S90). Un taux de survie significativement plus faible des juvéniles (stade 1 : 60,6-70,3\% et stade 2 : $56,1-67,3 \%$ ) est observé pour les groupes $\mathrm{S} 60, \mathrm{~S} 30$ et R. Mais le groupe R demande un gros travail coûteux. Les survies les plus faibles des juvéniles au stade $1(46,4 \pm 8,2 \%)$ et au stade $2(45,2 \pm 6,8 \%)$ sont observées en l'absence de traitement chimique et de retrait des œufs (C).

(1) University of South Bohemia in České Budějovice, Faculty of Fisheries and Protection of Waters, South Bohemian Research Center of Aquaculture and Biodiversity of Hydrocenoses, Zátiši 728/II., 38925 Vodňany, Czech Republic, policar@vurh.jcu.cz

(2) Moneycarragh Fish Farm, 60 Dromara Rd, Dundrum, Newcastle, County Down, BT33 ONS, Northern Ireland

(3) Cross-Border Aquaculture Initiative EEIG, 14-15 Grays Lane, Park St. Dundalk, Co. Louth, Republic of Ireland 


\section{INTRODUCTION}

Captive breeding of white-clawed crayfish, Austropotamobius pallipes (Lereboullet) can be considered such as an effective method for conservation and restoration of this endangered crayfish species (Reynolds, 1998; Reynolds et al., 2002; Policar et al., 2010). Effective production of juveniles in $A$. pallipes for reintroduction has used the artificial egg incubation (Al) of eggs (Policar et al., 2008).

Advances of the artificial incubation in European native crayfish were described by many authors (Cukerzis et al., 1978; Rhodes, 1981; Matthews and Reynolds, 1995; Pérez et al., 1998a, 1998b, 1999; Carral et al., 2003, 2004; Policar et al., 2006; Kouba et al., 2010b). The duration of the period of $\mathrm{Al}$ is generally dependent on the timing of the egg stripping and applied water temperature. We can distinguish a short-term (several days) and a long-term (several weeks) Al. The short-term Al is less demanding for energy, time, space and hatched juveniles are protected against female's cannibalism in the same way compared to longterm Al (Policar et al., 2006). The protecting hatched juveniles against females was published by Keller (1987) who used special containers with perforated bottom for the separation of juveniles from their females during juvenile detaching.

However, organic water contamination, and damaged or dead eggs are suitable substrates for fungi during Al (Vey, 1977; Policar et al., 2006). Therefore Al need to use the prevention of incubated live eggs against fungi invasion (Mason 1977; Rhodes 1981; Carral et al., 2004; Celada et al., 2004; Policar et al., 2006). Kouba et al. (2010b) summarized three techniques of fungi elimination during $\mathrm{Al}$ as antifungal treatments, removal of dead eggs or a combination of both.

Up to now, sodium chloride was not found to be a suitable antifungal bath during Al of crayfish eggs (Celada et al., 2004). However, the positive antifungal effect of this environmentally friendly agent has been described in freshwater finfish aquaculture during egg incubation by many authors (Marking et al., 1994; Froelich and Engelhardt, 1996; Schreier et al., 1996; Weirich and Tiersch, 1997; Khodabandeh and Abtahi, 2006; Rasowo et al., 2007).

The aim of this study was to compare the survival to stage 1 and stage 2 in $A$. pallipes eggs treated by three different concentrations of sodium chloride during $\mathrm{Al}$ as antifungal treatments.

\section{MATERIAL AND METHODS}

\section{> BERRIED FEMALES AND STRIPPING OF EGGS}

In total, 45 berried females (mean $\pm \mathrm{SD}$; total length $(T L)=85.9 \pm 7.1 \mathrm{~mm}$; carapace length $(C L)=38.2 \pm 3.3 \mathrm{~mm}$; body weight $(W)=17.5 \pm 4.1 \mathrm{~g}$ ) were used as a source of eggs for this study. All these females mated with 15 males $(T L=88.5 \pm 6.2 \mathrm{~mm} ; \mathrm{CL}=39.6 \pm 4.1 \mathrm{~mm} ; \mathrm{W}=$ $18.2 \pm 3.1 \mathrm{~g})$ under controlled conditions of one square tanks $\left(100 \times 100 \times 50 \mathrm{~cm} ; 1 \mathrm{~m}^{2}\right.$ surface area) in the Moneycarragh crayfish hatchery (Policar et al., 2009). After mating and egg laying, all males were removed from the tank. Berried females were kept in the tank under controlled water temperature what was decreased after egg laying from $8.0 \pm 0.3^{\circ} \mathrm{C}$ to $4.5 \pm 0.3^{\circ} \mathrm{C}$ over five days. After this initial period, females were kept under lowered temperature for 90 days, at $9.0 \pm 0.5{ }^{\circ} \mathrm{C}$ for 50 days, and $18.0 \pm 0.5^{\circ} \mathrm{C}$ for 5 days. In total, 3300 experimental eggs at embryonic phase XII, described by Celada et al. (1991), were stripped gently by tweezers from females after 150 days of maternal egg incubation.

\section{>ARTIFICIAL INCUBATION WITH ANTIFUNGAL TREATMENTS}

Immediately after stripping, all eggs were pooled and stocked into 18 one-liter bottles described by Policar et al. (2006). Each bottle was stocked with 110 eggs at an egg density of 6.9 eggs $\cdot \mathrm{cm}^{-2}$. Sodium chloride ( $\mathrm{NaCl} \geqslant 99.5 \%$; Sigma-Aldrich, Czech Republic) and 
formaldehyde (35.2\% formaldehyde; Dr Kulich Pharma, Czech Republic) were tested such as chemical antifungal treatments at three concentrations: S30 (30000 ppm), S60 (60000 ppm) and S90 (90000 ppm) and one concentration (as control to sodium chloride): F3 (3000 ppm), respectively. Other two groups were tested without fungicide chemicals with $(R)$ or without (C) the removal of dead eggs as controls to chemical treatments. All treatments were tested in triplicates. Each fungicide chemical treatment was applied to the eggs by a static bath once a three days with exposure of $15 \mathrm{~min}$ up to hatching (stage 1). The removal of dead eggs in group R was carried out with the same frequency as the application of chemical baths. After the hatching and the first juvenile moult, the number of stage 1 and stage 2 juveniles were recorded. During the first moulting period, juveniles in stage 2 were removed daily from each bottle according to recommendations to reduce juvenile cannibalism during Al (Melendre et al., 2007).

The recirculation system described by Policar et al. (2006) comprised storage and filtration tanks (total volume 400 L, Depur Systems, Northern Ireland), a pump (OceanRunner OR6500, AquaMedic, Germany), a heater system (T computer set with a $500 \mathrm{~W}$ heater, AquaMedic, Germany), 18 one-liter bottles (each with diameter $4.5 \mathrm{~cm}$ and internal surface area $15.9 \mathrm{~cm}^{2}$ ) and water distribution piping system (Depur Systems, Northern Ireland) was used for the $\mathrm{Al}$ of this study. Water was exchanged daily $(10 \%)$ with filtrated and tempered water from Moneycarragh River. Water flow through each bottle was stable around $1 \mathrm{~L} \cdot \mathrm{min}^{-1}$. Water temperature was automatically controlled by the heater system and measured by temperature loggers (RT-F53, Qi Analytical, Prague, Czech Republic) with a four hour interval. Average water temperature and oxygen saturation was $18.0 \pm 0.5{ }^{\circ} \mathrm{C}$ and $90.0 \pm 2.5 \%$, respectively during the whole Al. Dissolved oxygen levels were measured daily at $7 \mathrm{a} . \mathrm{m}$. with an oxymeter Pinpoint II (American Marine Inc., USA). Other water quality parameters such as $\mathrm{pH}$ (WTW MultiLine P4 probe, WTW GmbH, Germany), $\mathrm{NH}_{3}$ and $\mathrm{NO}_{2}^{-}$(Tetratest AnalySet, Tetra Company, Germany) were measured weekly. Average value of these parameters was: $\mathrm{pH}=7.5$; $\mathrm{NH}_{3}<0.02 \mathrm{mg} \cdot \mathrm{L}^{-1} ; \mathrm{NO}_{2}^{-}<0.01 \mathrm{mg} \cdot \mathrm{L}^{-1}$ during this study.

\section{> STATISTICAL ANALYSIS}

All data are presented as means $\pm \mathrm{SD}$. Statistical analysis of data was conducted using statistical software "Statistica 6.1" (StatSoft, Inc., Czech Republic). Results were subjected to one-way analysis of variance (ANOVA) after arc-sine transformation and assessing for normality and homoskedasticity with Kolmogorov-Smirnov and Levene's tests, respectively. Tukey's multiple comparison was used as a post hoc test. For all statistical tests, $P$ values $<0.05$ were considered to be significant.

\section{RESULTS}

Artificial incubation lasted for 32 days. Hatching began on day 18 and stage 2 was obtained from day 25. The period of the first moult lasted seven days. Juvenile survival rates to stage 1 and stage 2 from all treatments are summarized in Table I.

Formaldehyde treatment (F3 group) ensured high production of stage $1(89.7 \pm 2.3 \%)$ and stage $2(85.5 \pm 2.4 \%)$. Comparable survival rate to stage $1(85.5 \pm 5.5 \%)$ and $2(80.6 \pm 3.2 \%)$ were evident in treatment with the highest concentration of sodium chloride (S90). Lower survival rate of juveniles (stage 1: $60.6-70.3 \%$ and stage 2: $56.1-67.3 \%$ ) were evident in groups with lower concentrations of sodium chloride (S60 and S30) and control group with removal of dead eggs $(R)$. The lowest juvenile survival to stage $1(46.4 \pm 8.2 \%)$ and stage 2 $(45.2 \pm 6.8 \%)$ was found in the treatment without fungicide chemicals and removal of dead eggs $(C)$. 
Table I

Production of stage 1 and 2 juveniles (\% $\pm S D)$ after 32-days IA using different antifungal treartments in Austropotamobius pallipes.

Tableau I

Production de juvéniles de stades 1 et 2 d'Austropotamobius pallipes ( $\% \pm$ SD) après 32 jours d'incubation artificielle et différents traitements antifongiques.

\begin{tabular}{|c|c|c|c|c|c|c|}
\hline Group & $\mathrm{C}$ & $\mathrm{R}$ & $\mathrm{S30}$ & $\mathrm{S60}$ & $\mathrm{S90}$ & $\mathrm{F3}$ \\
\hline Stage 1 & $46.4 \pm 8.2$ & $68.8 \pm 5.2$ & $60.6 \pm 5.5$ & $70.3 \pm 6.2$ & $85.5 \pm 5.5$ & $89.7 \pm 2.3$ \\
& $\mathrm{~A}$ & $\mathrm{~B}$ & $\mathrm{AB}$ & $\mathrm{B}$ & $\mathrm{C}$ & $\mathrm{C}$ \\
\hline Stage 2 & $45.2 \pm 6.8$ & $65.2 \pm 5.0$ & $56.1 \pm 3.7$ & $67.3 \pm 2.4$ & $80.6 \pm 3.2$ & $85.5 \pm 2.4$ \\
& $\mathrm{~A}$ & $\mathrm{~B}$ & $\mathrm{AB}$ & $\mathrm{B}$ & $\mathrm{C}$ & $\mathrm{C}$ \\
\hline
\end{tabular}

Within a row, values without a letter in common are significantly different $(P<0.05)$ among treatments.

\section{DISCUSSION}

Intensive egg incubation in crayfish under controlled conditions needs to use effective antifungal treatment against fungal invasion in incubated eggs (Carral et al., 2004; Celada et al., 2004; Policar et al., 2006). Malachite green was used as the most effective fungicide for many years in aquaculture. However, the use of this chemical agent on food fishes and their eggs was prohibited for aquaculture in USA and EU since 1991 and 1997, respectively, because of its teratogenic and carcinogenic effects (Carral et al., 2009).

Formaldehyde is currently the most effective antifungal agent approved for using in aquaculture in USA and EU (Celada et al., 2004); however, its applying in aquaculture presents potential hazard for aquatic environment as well as farm staff (Arndt et al., 2001).

Therefore, new antifungal agents as alternatives to formaldehyde have been searched for Al. Jodisol preparation with povidonum iodinatum as active substance in a static bath and its combination with the removal of dead eggs (Policar et al., 2006) might be one possibility. Carral et al. (2009) tested three chemicals with copper hydroxide being the most effective one. Copper is ubiquitous in the enviroment. It is essential for all living organisms (among others, $\mathrm{Cu}$ is a core part of hemocyanin in crustaceans), and its body concentration is relativelly well regulated in crayfish (Kouba et al., 2010a). This chemical seams to be also an acceptable candidate as antifungal treatment for Al.

Our results showed that sodium chloride is also a very good antifungal agent suitable for artificially incubated crayfish eggs. Especially the bath with the highest concentration of sodium chloride $(90000 \mathrm{ppm})$ provided high survival to stage $1(85.5 \%)$ and stage $2(80.6 \%)$. Thefore we recommend to use this antifungal treatment for effective $\mathrm{Al}$ in $A$. pallipes eggs in practice. The benefit of this antifungal treatment is lower demand for labor and related costs and its environmental friendliness and user's safeness.

We tested routinely used static bath with $15 \mathrm{~min}$ exposure. Longer exposure of sodium chloride bath can decrease the concentration of sodium chloride such as effective antifungal treatment (Marking et al., 1994; Rasowo et al., 2007). However this hypothesis should be studied in further research. Longer exposition of sodium chloride will require next testing of peristaltic bath applying increased salinity in incubating systems.

Applying sodium chloride is well established in intensive aquaculture. It has been used as antifungal treatment in egg incubation of different freshwater fish species such as: Clarias garepinus, Cyprinus carpio, Oncorhynchus mykiss and Ictalurus punctatus (Marking et al., 1994; Froelich and Engelhardt, 1996; Schreier et al., 1996; Weirich and Tiersch, 1997; Khodabandeh and Abtahi, 2006; Rasowo et al., 2007). Increased salinity was also applied in intensive culture for increased survival and osmoregulatory of percid larvae (Krise et al., 1986; Guo et al., 1993; Bein and Ribi, 1994) and for control of fish diseases in intensive freshwater finfish culture (Mifsud and Rowland, 2008).

Weirich and Tiersch (1997) found positive effect of increased salinity (application of $1 \mathrm{~g}$ $\mathrm{NaCl} \cdot \mathrm{L}^{-1}$ ) in hatchery water on the hatching rate in I. punctatus. Sodium chloride at concentration 30000 ppm for a 60 min exposure period effectively inhibited fungal infection and 
increased the hatching rate of incubated eggs in Oncorhynchus mykiss (Marking et al., 1994). Rasowo et al. (2007) found an effective concentration of sodium chloride such as 1000 ppm with an exposure time 30 min for successful egg incubation of $C$. gariepinus. These authors also described the negative effect of higher concentrations of sodium chloride (i.e. 2000, 4000 and $10000 \mathrm{ppm}$ ) with the same exposure time for hatching in C. gariepinus. A similar negative effect of a high concentration of sodium chloride (2500 and $5000 \mathrm{ppm}$ ) during $60 \mathrm{~min}$ exposure on the hatching rate of $C$. carpio was confirmed by Froelich and Engelhardt (1996). However, this study did not observe such problem during $\mathrm{Al}$ in $A$. pallipes. This result can support and confirm considerible tolerance of crayfish to higher salinities (Kozák et al., 2009). Based on observed findings, the highest concentration of sodium chloride (90 000 ppm) applied once a three days for $15 \mathrm{~min}$ is recommended as an effective and safe antifungal treatment during $\mathrm{Al}$ of $A$. pallipes eggs in practice.

\section{ACKNOWLEDGEMENTS}

The authors of this paper gratefully thank Dr Julian Reynolds (Republic of Ireland) for English corrections. This investigation was financially supported by projects: INTERREG IIIA, CENAKVA (CZ.1.05/2.1.00/01.0024), NAZV (QH 71305), KONTAKT (ME 10125) and GAJU (047/2010/Z).

\section{REFERENCES}

Arndt R.E., Wagner E.J. and Routledge M.D., 2001. Reducing or withholding hydrogen peroxide treatment during a critical stage of rainbow trout development: effect on eyed eggs, hatch, deformities, and fungal control. N. Am. J. Aquacul., 63, 161-166.

Bein R. and Ribi G., 1994. Effects of larval density and salinity on the development of perch larvae Perca fluviatilis. Aquat. Sci., 56, 97-105.

Carral J.M., Sáez-Royuela M., Celada J.D., Pérez J.R., Melendre P.M. and Aguilera A., 2003. Advantages of artificial reproduction techniques for white-clawed crayfish (Austropotamobius pallipes Lereboullet). Bull. Fr. Pêche Piscic., 370-371, 181-184.

Carral J.M., Pérez J.R., Celada J.D., Sáez-Royuela M., Melendre P.M. and Aguilera A., 2004. Effects of dead egg removal frequency on stage 2 juvenile production in artificial incubation of Austropotamobius pallipes Lereboullet. Bull. Fr. Pêche Piscic., 372-373, 425-430.

Carral J.M., González A., Celada J.D., Sáez-Royuela M., Melendre P.M., González R. and Garcia V., 2009. Antifungal treatments in artificial incubation of crayfish eggs (Pacifastacus leniusculus, Astacidae): Searching for alternatives to formaldehyde. Knowl. Managt. Aquatic Ecosyst., 394-395, 16.

Celada J.D., Carral J.M. and González J., 1991. A study on the identification and chronology of the embryonic stages of freshwater crayfish Austropotamobius pallipes (Lereboullet, 1858). Crustaceana, $61,225-232$.

Celada J.D., Carral J.M., Sáez-Royuela M., Melendre P.M. and Aguilera A., 2004. Effects of different antifungal treatments on artificial incubation of the astacid crayfish (Pacifastacus leniusculus Dana) eggs. Aquaculture, 239, 249-259.

Cukerzis J.M., Sheshtokas A.L. and Terentyev A.L., 1978. Method for accelerated artificial breeding of crayfish juveniles. Freshwater Crayfish, 4, 452-458.

Froelich S.L. and Engelhardt T., 1996. Comparative effects of formalin and salt treatments on hatch rate of Koi carp eggs. Prog. Fish-Cult., 58, 209-211.

Guo R., Mather P. and Capra M.F., 1993. The effect of salinity on the development of silver perch Bidyanus bidyanus eggs and larvae. Comp. Biochem. Phys. A, 104, 531-535.

Keller M., 1987. Finding a profitabe population density in rearing summerlings of European crayfish Astacus astacus L.. Freshwater Crayfish, 7, 259-266.

Khodabandeh S. and Abtahi B., 2006. Effects of sodium chloride, formalin and iodine on the hatching success of common carp, Cyprinus carpio, eggs. J. Appl. Ichtyol., 22, 54-56.

Kouba A., Buřič M. and Kozák P., 2010a. Bioaccumulation and effects of heavy metals in crayfish: a review. Water Air Soil Poll., 211, 5-16. 
Kouba A., Carral J.M., Buřič M., Mráz J., Policar T. and Kozák P., 2010b. Artificial incubation of noble crayfish (Astacus astacus) eggs in a partial recirculating system using formaldehyde as antifungal treatment. Aquacult. Res., 41, e618-e623.

Kozák P., Policar T., Fedotov V.P., Kuznetsova T.V., Buřič M. and Kholodkevich S.V., 2009. Effect of chloride content in water on heart rate in narrow-clawed crayfish (Astacus leptodactylus). Knowl. Managt. Aquatic Ecosyst., 394-395, 08.

Krise W.F., Bulkowski-Cummings L., Shellman A.D., Krause K.A. and Gould R.W., 1986. Increased walleye egg hatch and larval surviva after protease treatment of eggs. Prog. Fish-Cult., 48, 95-100.

Marking L.L., Rach J.J. and Schreier T.M., 1994. Evaluation of antifungal agents for fish culture. Prog. Fish-Cult., 56, 225-231.

Mason J.C., 1977. Artificial incubation of crayfish eggs (Pacifastacus leniusculus Dana). Freshwater Crayfish, 3, 119-132.

Matthews M. and Reynolds J.D., 1995. The in vitro culture of crayfish eggs using a recirculating airlift incubator. Freshwater Crayfish, 8, 300-306.

Melendre P.M., Celada J.D., Carral J.M., Sáez-Royuela M. and Aguilera A., 2007. Effects of stage 2 juvenile removal frequency on final survival rates in artificial incubation of crayfish eggs (Pacifastacus leniusculus Dana Astacidae). J. Shellfish Res., 26, 201-203.

Mifsud C. and Rowland S.J., 2008. Use of salt to control ichthyophthiriosis and prevent saprolegniosis in silver perch, Bidyanus bidyanus. Aquacult. Res., 39, 1175-1180.

Pérez J.R., Carral J.M., Celada J.D., Sáez-Royuela M. and Romero M.P., 1998a. Effects of different thermal treatments throughout the embryonic development on the artificial incubation efficiency of crayfish (Austropotamobius pallipes Lereboullet) eggs. Control of the embryogenetic duration and implications for commercial production. Inver. Rep. Dev., 34, 253-258.

Pérez J.R., Carral J.M., Celada J.D., Sáez-Royuela M. and Romero M.P., 1998b. Effects of stripping time on the success of the artificial incubation of white-clawed crayfish, Austropotamobius pallipes (Lereboullet), eggs. Aquacult. Res., 29, 389-395.

Pérez J.R., Carral J.M., Celada J.D., Sáez- Royuela M., Muñoz C. and Antolín J.I., 1999. The possibilities for artificial incubation of white-clawed crayfish (Austropotamobius pallipes Lereboullet) eggs. Comparison between maternal and artificial incubation. Aquaculture, 170, 29-35.

Policar T., Kozák P. and Martin J., 2006. Effects of egg bath and daily removal of dead eggs on hatching success and production of stage 2 juveniles during artificial incubation in noble crayfish (Astacus astacus L.). Bull. Fr. Pêche Piscic., 380-381, 1197-1206.

Policar T., Flanigan M. and Smyth J.P., 2008. Intensive production of white-clawed crayfish (Austropotamobius pallipes) for restocking purposes in Ireland. Crayfish News, 30, 8-9.

Policar T., Smyth J., Flanigan M., Kozák P. and Kouba A., 2009. The effect of different cold period during maternal incubation on incubation efficiency and hatching term in Austropotamobius pallipes. Knowl. Managt. Aquatic Ecosyst., 394-395, 07.

Policar T., Smyth J., Flanigan M., Kozák P. and Kouba A., 2010. Optimum water temperature for intensive production of Austropotamobius pallipes (Lereboullet) juveniles. Freshwater Crayfish, 17, 51-55.

Rasowo J., Okoth O.E. and Hgugi C.C., 2007. Effects of formaldehyde, sodium chloride, potassium permanganate and hydrogen peroxide on hatch rate of African catfish Clarias gariepinus eggs. Aquaculture, 269, 271-277.

Reynolds J.D., 1998. Conservation management of the white-clawed crayfish Austropotamobius pallipes. Part 1, Irish Wildlife Manuals, No. 1, Dúchas The Heritage Service, Dublin, Ireland, 28 p.

Reynolds J.D., Démers A. and Marnell F., 2002. Managing an abundant crayfish resource for conservation - A. pallipes in Ireland. Bull. Fr. Pêche Piscic., 367, 823-832.

Rhodes C.P., 1981. Artificial incubation of the crayfish Austropotamobius pallipes (Lereboullet). Aquaculture, 25, 129-140.

Schreier T.M., Rach J.J. and Howe G.E., 1996. Efficacy of formalin, hydrogen peroxide, and sodium chloride on fungal-infected rainbow trout eggs. Aquaculture, 140, 323-331.

Vey A., 1977. Studies on the pathology of crayfish under rearing conditions. Freshwater Crayfish, 3, 311-319.

Weirich C.R. and Tiersch T.R., 1997. Effects of environmental sodium chloride on percent hatch, yolk utilization and survival of channel catfish fry. J. World Aquacult. Soc., 28, 289-296. 